\title{
Assessing Needle Exchange Operations in a Poor Brazilian Community
}

\author{
FRANCISCO I. BASTOS, ${ }^{1}$ MONICA MALTA, ${ }^{1}$ \\ MARIANA A. HACKER, ${ }^{1}$ MAYA PETERSEN, ${ }^{1,2}$ \\ MIRTHA SUDBRACK, ${ }^{3}$ MARCIA COLOMBO, ${ }^{3}$ AND \\ WALESKA T. CAIAFFA, ${ }^{4}$ on behalf of Project AjUDE II \\ ${ }^{1}$ Oswaldo Cruz Foundation (FIOCRUZ), Rio de Janeiro, Brazil \\ ${ }^{2}$ University of California, Berkeley, CA, USA \\ ${ }^{3}$ Porto Alegre Harm Reduction Project, Rio Grande do Sul, Brazil \\ ${ }^{4}$ Federal University of Minas Gerais (UFMG), Minas Gerais, Brazil
}

\begin{abstract}
This article assesses the operations of Porto Alegre, State of Rio Grande do Sul, (southern Brazil) needle exchange program (NEP), a setting where HIV infection rates have been on the rise among injection drug users (IDUs) in recent years, contrasting with substantial declines observed in this population, in major Brazilian cities (located in the southeast and southernmost part of Brazilian northeast). We explored local syringe dynamics, with the exclusive delivery in the local NEP of tagged syringes, and the subsequent monitoring of returned tagged/untagged used syringes from January to September 2002. We further assessed local NEP operations using focus groups and field observation, trying to expose the underlying reasons for the substantial delay in the return of tagged syringes and the continuous and relevant return of untagged syringes throughout the study period. We found that local IDUs reuse, divert, and create caches of syringes at their discretion. All efforts should be made to increase the availability of clean syringes and to fully integrate syringe exchange with comprehensive health education and health screening to effectively curb HIV spread.
\end{abstract}

Keywords injection drug users (IDUs); needle exchange program (NEP); resident agents; risk behaviors; satellite exchange; syringe circulation; tagged syringes

\section{Introduction}

Since the mid-1980s, needle exchange programs (NEPs) have been introduced in a growing number of developed and developing countries (Crofts et al., 1998; Gray, 1998; Bastos and Strathdee, 2000; Andrade et al., 2001; Caiaffa et al., 2003a, 2003b, 2003c; MacDonald et al., 2003; Sharma et al., 2003). By exchanging used syringes for sterile ones, NEPs protect injection drug users (IDUs) from acquiring bloodborne infections, such as HIV and hepatitis B and C. Most NEPs also provide HIV/AIDS education, condoms, and, when available, referrals to drug abuse treatment programs and medical services (Porter et al., 2002; Riley et al., 2002).

Address correspondence to Francisco Bastos, DIS/CICT Fundacao Oswaldo (FIOCRUZ), Av. Brasil 4365, Biblioteca de Manguinhos \#209, Rio de Janerio 21045-900, Brazil. E-mail: bastos@cict.fiocruz.br 
Estimating the effectiveness of NEPs is complex, and studies have yielded conflicting results. Most NEP evaluations have shown that drug users report reduced risk behaviors, including reduced needle sharing, after initiating NEP attendance (Lurie et al., 1993; Hagan et al., 1995; Heimer et al., 1998; Gibson et al., 2002). However, self-report data are prone to bias. Despite evidence that sociodemographic and behavioral information provided by IDUs is quite reliable (Darke, 1998; Menoyo et al., 1998), several studies comparing traditional self-report to audio computer-assisted self-interview have shown that IDUs tend to under-report needle-sharing behaviors (Des Jarlais et al., 1999; Metzger et al., 2000) and to over-report protective behaviors such as condom use (Macalino et al., 2002) on interviewer-administered questionnaires.

Few studies have compared HIV incidence among NEP attendees with incidence among nonattendees (Kaplan et al., 1994; van Ameijden et al., 1994; Des Jarlais et al., 1996; van Ameijden and Coutinho, 2001). Although most studies suggest that NEPs reduce HIV incidence among participants, some have reported elevated incidence rates among NEP attendees (Bruneau et al., 1997; Strathdee et al., 1997; Hagan et al., 1999). The conflicting reports surrounding NEP effectiveness have incited much debate (Bastos and Strathdee, 2000; Vlahov et al., 2001), creating an unfavorable environment to NEP funding and operation. Worldwide, most NEPs operate in conditions that impair the effective accomplishment of their mandates, sometimes facing the open opposition of powerful political and cultural forces (Lurie, 1995; Sorge and Harlow, 1997; Case et al., 1998; Gostin, 1998).

NEPs were introduced in Brazil in 1994, in Salvador, Bahia, and now exist throughout the country. A consortium of state, federal, and international institutions and agencies supported the introduction of NEPs to Brazil (Andrade et al., 2001; Bastos and Strathdee, 2000). In three Brazilian cities a consistent decline was observed in the seroprevalence of hepatitis B and C, human lymphotropic virus types I/II, and HIV among IDUs after introduction of NEPs in the mid-1990s (Mesquita et al., 2001; Bastos et al., 2002a; Dourado et al., 2002), although it is not clear that these effects are the direct result of NEP services. In contrast, HIV prevalence has not declined among IDUs in the Brazilian south (Bastos et al., 2002b) and seems to be increasing in sites such as Porto Alegre, the capital of Brazil's southernmost state, Rio Grande do Sul (Caiaffa et al., 2003a). This increase is occurring despite existence in the region of NEPs and HIV treatment and prevention programs equivalent to the rest of Brazil.

Very little data are available about the operations and coverage of Brazilian NEPs, in the south or elsewhere. Other than publications by members of our group based on the multisite NEP evaluation project described in this article, two articles in the peer-reviewed literature address the operations of Brazilian NEPs (Telles, 1999; Andrade et al., 2001). In addition, two articles (Strathdee et al., 1998; Bastos and Strathdee, 2000) reviewed the implementation of Brazilian NEPs within the framework of international efforts to reduce drug-related harm and curb the spread of HIV and viral hepatitis in IDUs.

The paucity of operational data is likely due in part to a general absence in Brazilian public health of an institutional culture emphasizing program evaluation. In addition, many Brazilian NEPs have "surfaced" from underground/erratic operations very recently. The majority remain underfunded and understaffed, forcing them to concentrate their scarce human and material resources on the operation of programs and projects rather than on their evaluation.

Failure to curb the HIV epidemic among IDUs in southern Brazil may be due in part to operational difficulties of NEPs in the region. To explore this hypothesis, we analyzed syringe and needle circulation in Porto Alegre, a poor community of southern Brazil. As 
data on NEP operations in Brazil improve, we hope in the future to be able to compare our findings from Porto Alegre with data from Brazilian NEPs located in regions where HIV and other bloodborne infection rates have been declining.

\section{Background: Porto Alegre and the Porto Alegre NEP}

Porto Alegre is a key metropolis of the Latin American southern cone and its free-trade area, Mercosul. Porto Alegre has approximately 1,360,000 inhabitants, with a sizeable middleclass composed primarily of European immigrants. Migration to Porto Alegre from smaller Brazilian cities and the countryside has increased during the past two decades, with most migrants living in substandard conditions on the outskirts of the city and/or in slums located on inner-city hills. Economic crisis and its sequelae (high unemployment rates, bankruptcy of small businesses, impoverishment of small landowners in the capital outskirts, and migration of landless peasants) have progressively added new layers of precarious dwellings to underserved and marginalized communities. It is in these communities that most IDUs drug users live and congregate.

The Porto Alegre NEP (locally known as the "Porto Alegre Harm Reduction Program") was established in 1996. Since its foundation, the NEP has developed a fruitful partnership with the public health system and municipal and state authorities. This cooperation has decreased the program's operational costs and has helped to reduce the barriers frequently faced by NEP worldwide, including confrontations with the judiciary system and the police and mistrust on the part of the official health system. Lower costs and good governmental relations have also improved the economic sustainability of the Porto Alegre program, in contrast to NEPs in the United States, where government funding of NEPs is banned federally. (Details about the American context are available in Lurie, 1995.)

Unlike most Brazilian NEPs, the Porto Alegre program did not originate in the local drug user treatment centers, necessitating the de novo construction of institutional links between the NEP and drug user treatment services. Referral from and to drug user treatment centers remains far from optimal. Barriers to full collaboration between the institutions include remaining conflict between the harm-reduction focus of the NEP and the strict abstinence approach of some drug user treatment practitioners.

The work of the Porto Alegre NEP comprises exchange of syringes, counseling, and basic health care. In addition to the exchange of packs of syringes, the program distributes "prevention kits." These kits are made up of a small case containing two 1-ml syringes, two spare $13 \times 25$ needles, two swabs, two condoms, distilled water, a pot for dilution, an information leaflet, and a card with the NEP address and telephone number. In 2002, the Porto Alegre program distributed approximately 150,000 sterile syringes, 120,000 condoms, 450,000 swabs, and 200,000 leaflets and posters (Colombo et al., 2003).

Clean syringes and other drug injection paraphernalia are delivered both by fixed NEP posts and by mobile teams composed of at least two outreach workers. The mobile teams regularly visit 21 different areas, primarily using public transportation. Used syringes are collected daily from the posts and from each of the areas served by outreach workers. Although the program's goal is to exchange used syringes for clean ones, there is no "one-for-one" exchange rule and the number of syringes returned through the official system of yellow disposal boxes corresponds to roughly half of the syringes distributed in a given year (73,000 returned vs. 150,000 distributed in 2002, Colombo et al., 2003). 
A large team of 42 community volunteers and 12 paid outreach workers work for the Porto Alegre program. In addition, the NEP has been serving as a training field for graduate students under the supervision of faculty from the local universities and professionals active in the program. This integration has opened up new areas of multidisciplinary interaction and has functioned as an important support for the routine activities of outreach workers. A former study, using the capture-recapture methodology, estimated that Porto Alegre NEP had about 320 regular attendees in 1998 (Caiaffa et al., 2003c). No reliable estimate for the global number of people injecting illicit drugs in Porto Alegre exists, but informed guesses estimate between 7,000 and 8,000 IDUs in the area (Colombo et al., 2003).

The receptivity of the local communities has played a crucial role in Porto Alegre NEP operations. Community relations benefit from the presence of ex-IDUs as peer educators in the NEP. A unique feature of the program is the work of the agentes moradores ("resident agents") who, in addition to the activities described in the international literature on "secondary exchangers" or "satellite exchangers" (Valente et al., 1998; Tyndall et al., 2002; Snead et al., 2003), volunteer to exchange syringes and needles in their own homes or shanties when the official exchange point is closed or when the outreach workers are not in the area. Reports from Brazilian NEPs in other regions, available in the "gray" literature retrievable on the internet (see websites in the Appendix) suggest that these "resident agents" are unique to southern Brazil.

Finally, the Porto Alegre harm reduction program works in conjunction with other community programs, including a roving theater that visits local needy communities. Children in these communities are often employed by drug dealers as olheiros (watchers) and paid in cash, drugs, or favors for warning of the approach of police patrols. The excellent reception of the theater program among these children allows the children to enjoy some contact with health promotion programs (Bastos, 2000).

\section{Methods}

The results presented in this article are part of a comprehensive evaluation of six Brazilian NEPs (The AjUDE II Project). A survey and seroepidemiological study was carried out in six localities, detailed elsewhere (Caiaffa et al., 2003a, 2003b, 2003c). Qualitative studies have been also implemented in the current and previous round of Brazilian NEP evaluation (Deslandes et al., 2002). This study was carried out in the Porto Alegre NEP, which serves a population of injection drug users from poor communities (vilas or favelas).

Based on the concepts proposed by Kaplan and Heimer (Kaplan, 1994; Heimer et al., 2002), we focus on the dynamics of syringe circulation rather than on the risk behaviors and infection status of NEP attendees. From January to June 2002, the Porto Alegre NEP distributed only tagged syringes: syringes with a purple plunger, unavailable in Brazilian pharmacies and never distributed before in Brazil. During this 6-month period, a total of 50,000 sterile syringes with purple plungers were distributed through the habitual venues of the NEP. For 9 months after study initiation (January to September), we opened and analyzed the contents of returned disposal boxes, counting the number of tagged and untagged syringes.

We used qualitative methods to further investigate syringe dynamics from the point of view of individuals and their networks. Methods included focus groups and field observations recorded daily by outreach workers and by workers in charge of daily program operations. Focus group participants were recruited from two major slums served by 
the Porto Alegre NEP. Participants were asked about HIV infection risks, positive and negative aspects of the NEP, and relationships with outreach workers. In addition, their access to services was discussed, including access to sterile syringes and other injection equipment, to counseling and testing for HIV and hepatitis B and C, and to general health care. Participants were also asked for recommendations to improve current NEP operations.

The present article addresses the findings of six focus groups, with a mean of nine attendees each. A former article by members of the same research team explores in detail findings from field ethnography and in-depth interviews (Deslandes et al., 2002), but this material has not been used here.

\section{Results}

A total of 555 boxes was distributed and collected during the study period. On average, 73.6 units of any injection paraphernalia (i.e., complete syringes-syringes plus needles or avulsed syringes or needles) were counted in a disposal box.

\section{Contents of Returned Disposal Boxes}

Approximately one third of disposal boxes (27\%) that were returned from January to September 2002 had at least one tagged syringe; most disposal boxes returned during the study period did not contain tagged syringes. During the period when the Porto Alegre NEP distributed only tagged syringes, $90.8 \%$ of all returned syringes were untagged. A range of other injecting paraphernalia was returned to the disposal boxes, as depicted in Table 1.

The number of nontagged syringes returned via disposal boxes declined during the period during which only marked syringes were distributed and rose sharply 2 months after the NEP resumed distribution of untagged syringes (Figure 1). A substantial number of untagged syringes continued to be returned throughout the period during which only tagged syringes were distributed, reaching a minimum of 764 untagged syringes returned in July, 8 months after the initial distribution of exclusively tagged syringes.

\section{Table 1}

Contents of disposal boxes collected by the Porto Alegre NEP, Porto Alegre, RS, Brazil, January-September 2002

\begin{tabular}{lcrrr}
\hline $\begin{array}{l}\text { Type of injection } \\
\text { paraphernalia }\end{array}$ & $\begin{array}{c}\text { Number of disposal } \\
\text { boxes containing } \\
\text { paraphernalia }(\%)\end{array}$ & $\begin{array}{c}\text { Mean } \\
\text { number } \\
\text { per box }\end{array}$ & $\begin{array}{r}\text { Median } \\
\text { number } \\
\text { per box }\end{array}$ & $\begin{array}{r}\text { Standard } \\
\text { deviation } \\
\text { per box }\end{array}$ \\
\hline Tagged syringes & $149(26.85)$ & 36.72 & 18.00 & 69.64 \\
Untagged syringes & $512(92.25)$ & 48.30 & 22.00 & 236.22 \\
$\begin{array}{l}\text { Incomplete syringes } \\
\quad \text { (no needles) }\end{array}$ & $420(75.67)$ & 9.43 & 5.00 & 11.48 \\
Needles & $391(70.45)$ & 17.07 & 8.00 & 30.80 \\
Filters & $3(.54)$ & 1.33 & 1.00 & .58 \\
\hline
\end{tabular}


Number of returned syringes

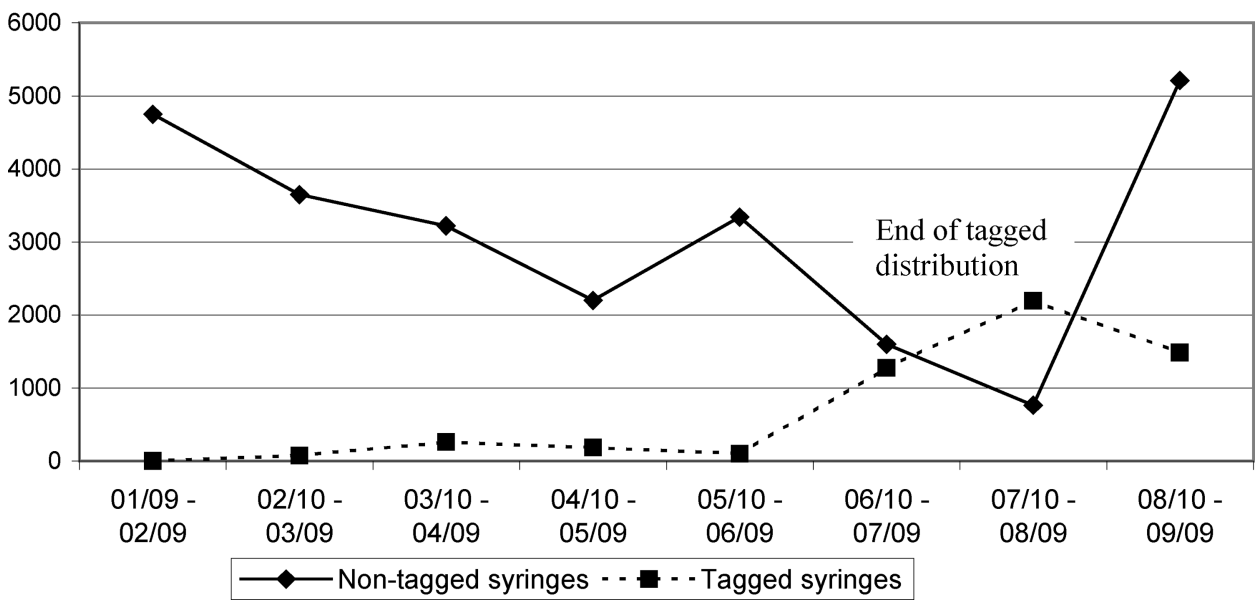

Figure 1. Number of untagged syringes returned during the 9-month study period.

\section{Findings from Focus Groups and Field Notes}

Most attendees of the focus groups and people contacted in the field reported that they collect more syringes in the NEP than they need for their own use and distribute or sell syringes to their acquaintances. In contrast to previous reports (Valente et al., 1998; Tyndall et al., 2002), attendees not only distribute extra syringes in the field (while, most of the time, collecting used syringes, i.e., the traditional definition of "satellite exchange") but also accumulate stocks of sterile syringes and other materials, including disposal boxes, in their own homes. Such injectors' homes (most of them barracos, shanties) function as a cache of injection paraphernalia, visited by different drug users from the community. Such home-based satellite exchanges generally function as a complimentary "service" provided to acquaintances and friends but sometimes provide a source of revenue. Home-based sale of drug injection paraphernalia was particularly prominent in shanties located far away from the NEP office, not usually reached by the mobile team, and/or after hours (i.e., when drug users craving a fix couldn't get paraphernalia for free).

Shanties that deliver paraphernalia and occasionally small amount of drugs in exchange for money may resemble North American "shooting galleries" at first glance, but unlike their North American counterparts the revenues of these home-based exchanges are minimal and their operation is completely disorganized. Operators of these home-based exchanges are not considered by the community to be "dealers" but rather "friends" of the local NEP, locally known as agentes moradores (resident agents). The approximately 40 regular resident agents in Porto Alegre play a key role in the current operations of the program, handling no less than $50 \%$ of all clean syringes delivered by the NEP every day, according to outreach workers and clients.

In contrast, individuals who are considered "dealers" (locally known as patroes, i.e., bosses/lords) do not sell drugs in their homes, move around in heavily armed bands, and sell most of their merchandise to nonresidents of the community. There were no reports of joint sales of drugs and drug injecting paraphernalia by the dealers themselves. Previous findings from a companion study documented that dealers are very seldom mentioned by 
local IDUs as a relevant source of clean syringes, and when they are used as a source, it is typically only for the first injection in an IDU's injecting history. The dealers were not cited as a source of clean syringes for any injections other than the very first in former analyses (Caiaffa et al., 2003a, 2003b, 2003c).

Study participants reported that NEP syringes have been diverted at times through extended networks, passed or sold to other communities where there is no NEP, or even smuggled into prisons, where drug paraphernalia is sold at high prices. As shown elsewhere (Caiaffa et al., 2003a, 2003b), syringes are seldom returned directly to disposal boxes after a single use but are rather reused many times until their needles are no longer sharp or are passed or sold to other users.

\section{Discussion}

The dynamics of syringe exchange in Porto Alegre were investigated by distributing exclusively tagged syringes and analyzing the contents of returned syringe disposal boxes. Although the number of returned untagged syringes declined after initiation of tagged syringe distribution, large numbers of untagged syringes continued to be returned to the Porto Alegre NEP throughout the study period. In addition, only some disposal boxes contained tagged syringes, and the return of tagged syringes, increased only toward the end of the observation period, with no identifiable cluster of better/faster return.

One aim of the current project was to assess the feasibility of establishing a formal tracking system, similar to the one described by Kaplan and Heimer (Heimer et al., 1998, 2002; Kaplan, 1994; Kaplan et al., 1994), in the Brazilian context. As a feasibility study, no systematic effort was made to track tagged syringes returned to nonofficial collection venues. Our results suggest that further evaluation and revision of NEP operations should be completed before other costly and time-consuming components of Kaplan and Heimer's original New Haven initiative, such as the introduction of a more sophisticated tagging process or PCR testing of returned syringes, are implemented (Heimer et al., 1998, 2002; Kaplan 1994; Kaplan et al., 1994).

In a region served by a well-functioning NEP, with high program coverage and an exchange ratio of used (returned) to clean (delivered) syringes approaching one to one, the return of untagged syringes would be expected to be much less prevalent and sustained than we observed in this study. In theory, the more closely the supply of syringes provided by the NEP is matched to the number of syringes used by the community, the less delay that will be observed between the use and return of untagged syringes previously distributed by the program and the fewer syringes that will be provided by alternate sources. In this setting, distribution of exclusively tagged syringes should result in a steep decline in the number of untagged syringes returned, as untagged syringes previously distributed by the program are exchanged for new tagged syringes. Numbers of unmarked syringes returned should decline particularly rapidly in a drug use setting predominantly involving injection of cocaine, as exists in Porto Alegre (Caiaffa et al., 2003a, 2003b, 2003c), given the characteristic binge pattern of cocaine self-injection (Anthony et al., 1991).

The sustained numbers of untagged syringes returned to the Porto Alegre NEP observed in this study suggest two potential shortcomings in the needle exchange services provided: (1) A substantial delay may exist between NEP syringe distribution and return, and (2) syringes may be supplied by a major source or sources other than the NEP. A third possibility is that the findings of this study are not be representative of normal Porto Alegre NEP operations; for example, IDUs may have treated tagged syringes differently 
from standard syringes distributed by the NEP, perhaps due to concern over the colored plunger.

We explored these possibilities using qualitative methods. No study participants mentioned resistance to, or concern about, use of the tagged syringes. Focus groups and field notes revealed that clean syringes and needles delivered by the NEP are substantially reused, with a single needle often used for more than 20 injections over 2 days. In addition, participants reported the frequent diversion of syringes and the existence of large stocks of clean syringes accumulated by the resident agents.

The impact of the resident agents on NEP operations cannot be easily summarized. From one point of view, redistribution by the resident agents does not have necessarily a detrimental effect, because it may facilitate distribution of sterile syringes to IDUs who might not otherwise receive them (Valente et al., 1998; Tyndall et al., 2002; Snead et al., 2003) and may constitute a key strategy for delivery of sterile equipment to dispossessed and mobile populations (Sears et al., 2001). Redistribution also provides a potential source of clean paraphernalia during hours when NEP services are not available.

On the other hand, the fact that large numbers of NEP syringes are being diverted into individual caches and from there redistributed subjects the flow of syringes in this community to drug users' own discretion. Resident agents may charge small fees for equipment distributed by the public health system at no cost, potentially impeding access. In addition, the uneven redistribution of resident agent's caches may create transient geographic or temporal imbalances between drug users demand for clean syringes and syringe availability, compromising the planning and monitoring of public policies by local health authorities and complicating efforts to estimate NEP coverage.

The selling of equipment made available at no cost by a network of public institutions - even if the prices are lower than those practiced in the pharmacies — challenges the philosophy of professionals and activists used to work in a country where free access to health care-including provision of antiretroviral medicines for those living with HIV/AIDS - is a cornerstone of public health and a key statement of the Brazilian federal constitution, embodying the struggle against social exclusion fostered by more than two decades of dictatorship. The Brazilian context must be clearly contrasted with the North American scene, where there are laws regulating the purchase and possession of injection equipment and where street sellers have a meaningful role as sources of injection equipment (Stopka et al., 2003).

According to the Kaplan-Heimer model, a primary means by which NEPs are postulated to impact HIV transmission risk is by accelerating the removal of used and thus potentially contaminated syringes from community circulation (Kaplan, 1994). The extensive reuse and diversion of syringes and the existence of parallel stocks of syringes in Porto Alegre may both act to increase the delay between syringe distribution and removal, thus compromising the preventive the impact of the Porto Alegre NEP. Because the local NEP does not require one-for-one exchange of syringes, there does not seem to be an incentive for IDUs and resident agents to return syringes. A key question to be addressed by future operational research is whether strict enforcement of a one-for-one exchange policy could stimulate the return of used syringes and the timely distribution of equipment from private caches.

Syringes supplied by sources other than the NEP almost certainly also contributed to the continued return of unmarked syringes observed during the study period. No other NEPs exist in the area, and pharmacy-based needle exchange is not used in Brazil. However, the 
possession of injecting equipment is legal in Brazil, and injecting equipment can be readily purchased without prescription in pharmacies (prescription and paraphernalia laws have never existed in Brazil). Indeed, in Porto Alegre, syringes and other injecting paraphernalia have been found for sale in bars close to drug selling points (F.I.B., field notes from preliminary site visit). In addition, previous work suggests that IDUs in Porto Alegre procure syringes from alternative sources, including friends, relatives, and drug dealers (Caiaffa et al., 2003b).

The existence of significant alternative sources of syringes potentially compromises the impact of the Porto Alegre NEP. Unlike the Porto Alegre NEP, neither pharmacies nor alternative services provide preventive services coupled to needle distribution. In addition, the prominent role played by alternative sources of syringes suggests that the Porto Alegre NEP is not providing a sufficient number of syringes to meet the needs of the community that it serves; in other words, program coverage is clearly not optimal. Actual program coverage achieved is a pivotal factor in the success of NEPs (Remis et al., 1998; Coffin 2002), in addition to their accessibility and the range and quality of services they provide (as discussed in detail in Bastos and Strathdee, 2000).

Heated debate continues about the effectiveness of NEPs in reducing the transmission of HIV and other bloodborne pathogens (Lurie, 1995; Vlahov et al., 2001). Some authors have used the conflicting results of studies assessing the impact of NEP to argue against the use of NEPs as a prevention strategy (as discussed by Bastos and Strathdee, 2000; Vlahov et al., 2001). However, the effectiveness of the needle exchange strategy cannot be assessed based on the impact of programs with substantial operational shortcomings. Our results illustrate the need for site-specific evaluation of NEP operations, on a continuous basis, before any attempt is made to estimate the impact of such programs.

A concerted effort to increase the availability of clean syringes and to fully integrate syringe exchange with health education and health screening should be made in Porto Alegre and other southern sites where HIV infection rates are far from being curbed. Improved program functioning and continuous monitoring could help to decrease the formation of private syringe stocks and the frequency of syringe diversion and resale. Resident agents should be trained and supervised and fully integrated into the daily activities of the program. This process will include validating their efforts and offering them material incentives through the NEP, while discouraging any direct payment in exchange for clean injection equipment. Provision of material incentives has already been implemented by other Brazilian community programs and can include free access to public transportation, coupons for basic food and domestic supplies, and support for children attending day cares and schools. The unabated transmission of HIV among IDUs in the Brazilian south makes such integrated attempts mandatory and urgent, particularly given the social inequality and structural violence which prevails in Brazil's impoverished communities.

\section{Glossary}

Agentes Moradores (Resident Agents): Members of the community working voluntarily for the project, using their own houses or shanties to (re)distribute injection equipment and other preventive materials delivered by the program.

Barracos (Shanties or Huts): Precarious habitations in a favela. 
Favelas: Brazilian denomination for shantitowns or slums. In the southern regions the word vilas is frequently used as a synonym for favela, whereas in the rest of the country the word vila means a row of regular houses enclosed in a given space.

Olheiros (Watchers): People paid or somewhat supported by the local dealers to warn them every time a police patrol cross the limits of the selling area (called boca, literally "mouth").

Patroes: Literal translation "bosses" or "lords," denomination local communities give to drug dealers.

\section{RÉSUMÉ}

Ce travail évalue l'opération quotidienne d'un Programme d'Échange de Seringues (PES) de Porto Alegre, Rio Grande do Sul (sud du Brésil), un contexte où les taux d'infection par le VIH s'élèvent depuis les dernières années parmi les utilisateurs de drogue par injection (UDI), ce qui contraste avec les déclins substanciels qui sont observés dans cette population, dans les plus grandes villes brésiliennes des régions sud-est et (portion sud du) nord-est. Nous avons examiné la dynamique des seringues à travers la distribution exclusive de seringues marquées de la part du PES local et le postérieur contrôlement des seringues marquées/non marquées renvoyées au PES, de janvier a septembre de 2002. Nous avons encore exploré les opérations du programme de cette communauté-là par le biais de groupes focaux et de l'observation de la scène de consommation, tout en essayant de mettre en évidence les raisons subjacentes au retard substanciel du renvoi des seringues marquées et du renvoi considérable et continu de seringues non marquées, le long de toute la période d'observation. Nous avons constaté que les UDI de cette communauté-là réutilisent, remanient et créent des stocks de serigues et d'aiguilles, de façon idiosyncrasique. On doit, par tous les moyens possibles, amplifier la mise à disposition de seringues nettes (stériles) et intégrer l'échange de seringues par d'amples actions d'éducation pour la santé et triage de possibles infections et d'autres conditions morbides, de manière à interrompre, effectivement, la dissémination du VIH.

\section{RESUMEN}

Este artículo procede a una evaluación de la operación cotidiana de lo Programa de Cambio de Jeringas (PCJ) de Porto Alegre, estado do Rio Grande do Sul, (en el sur de Brasil), localidad en que se ha observado un ascenso de las tasas de infección por el VIH en los últimos años, en la población de usuarios de drogas inyectables (UDI), en contraposición con lo descenso expresivo que se ha observado en las más grandes ciudades brasileñas de las regiones sudeste y (el sur del) nordeste.

Examinamos la dinámica de las jeringas por intermedio de la distribución exclusiva de jeringas marcadas por lo PCJ de aquella comunidad y posterior monitoreo de las jeringas marcadas/no-marcadas retornadas a lo PCJ, de enero a septiembre de 2002. Evaluamos aún la operación del PCJ por intermedio de grupos focales y observación de la escena de consumo de drogas, buscando hacer patente los motivos subyacentes al retardo expresivo del retorno de las jeringas marcadas e del retorno relevante y continuo de jeringas no-marcadas, durante todo el período de observación. Ha sido evidenciado que los UDI de la comunidad local reutilizan, cambian de dirección y crian reservas de jeringas y agujas, de manera idiosincrásica.

Débese, por todos los medios, ampliar la disponibilidad de jeringas limpias (estériles) y de integrar el cambio de jeringas con las iniciativas de educación para la salud y identificar de 
pronto las infecciones y otras condiciones morbosas, de modo a efectivamente interrumpir la diseminación del VIH.

\section{THE AUTHORS}

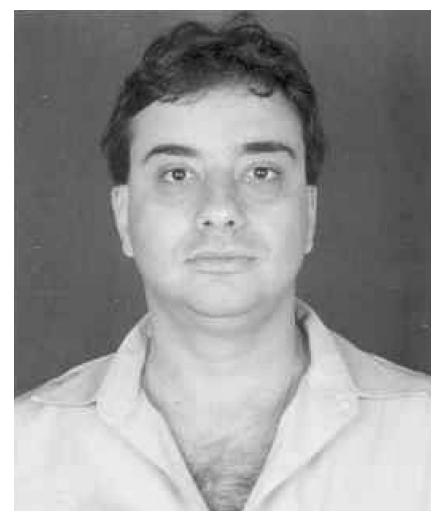

Francisco I. Bastos, M.D., Ph.D. (Brazil), is a Senior researcher at the Oswaldo Cruz Foundation, Rio de Janeiro, Brazil. He has been working for more than 20 years in the field of substance use prevention and care. Since 1990, Dr. Bastos has been studying the spread of HIV and other bloodborne infections among injection drug users and, more recently, has been working with HIV/AIDS among other vulnerable populations, such as women from underserved communities. Dr. Bastos has (co-)authored over 120 papers and/or book chapters on drug use, HIV/AIDS and related themes, and has worked on multiple collaborative projects such as the US NIH-sponsored HIV Prevention Trials Network (HPTN), different WHO Multicity studies, and as an honorary visiting researcher at the Imperial College, UK.

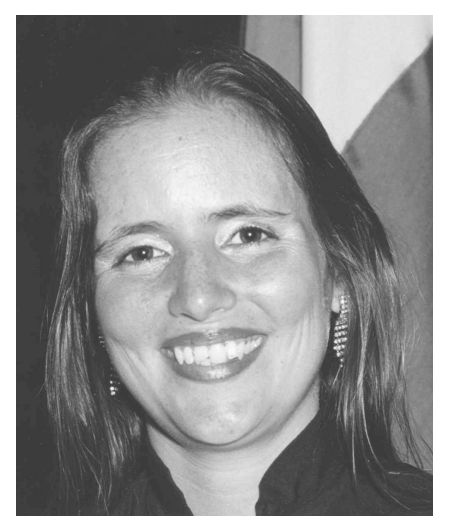

M. Malta, M.P.H., is a junior researcher at the Oswaldo Cruz Foundation, Rio de Janeiro, Brazil. She worked as a visiting researcher at the Johns Hopkins University, sponsored by NIDA in 2004-2005. Ms. Malta is responsible for a research project evaluating the access and adherence to ARV therapy among HIV-positive drug users in Brazil and developed with Dr. Bastos the first guideline for the treatment of HIV-positive cocaine users in Latin America, sponsored by the Pan-American Health Organization and the Brazilian Ministry of Health.

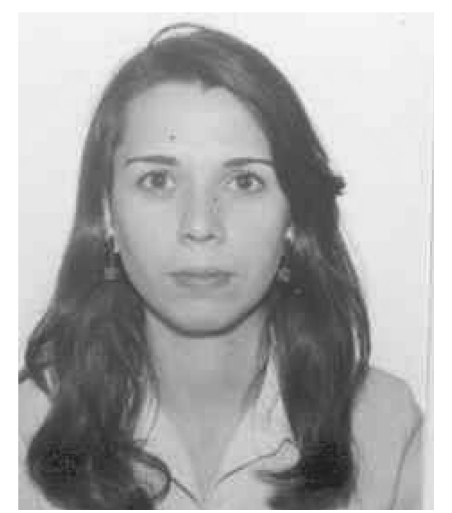

M. A. Hacker, M.P.H., Ph.D. 26, graduated in statistics in 2000 and received her Ph.D. in 2006. She joined Oswaldo Cruz Foundation (FIOCRUZ), working first as a trainee and later as a statistician for the WHO Drug Injection Study Phase II. Dr. Hacker received her Ph.D. at Oswaldo Cruz Foundation in 2006, mentored by Francisco I. Bastos. Currently, the FIOCRUZ team is dedicated to the analysis of Brazilian major databanks in the field of HIV/AIDS, in cooperation with the Imperial College, UK, and profiting also from a formative grant from NIH, USA. 


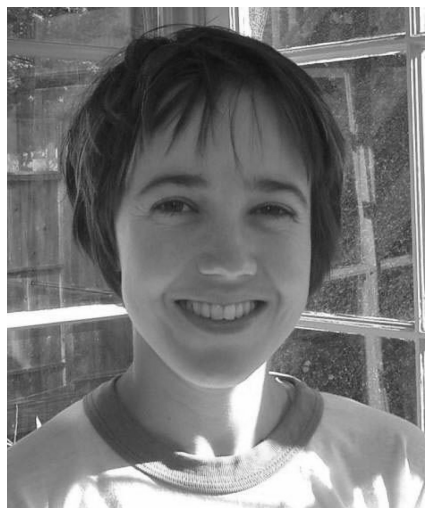

M. Petersen, M.S., is currently pursuing joint M.D./Ph.D degrees from the University of California, San Francisco and the Dept. of Biostatistics at the University of California, Berkeley. Ms. Petersen spent the year of 2003 in Rio de Janeiro, Brazil, collaborating with the team of Francisco I. Bastos at the Oswaldo Cruz Foundation in the analysis of trends in the Brazilian HIV/AIDS epidemic and access to care by vulnerable populations. Her current research is focused on the treatment of HIV resistant to antiretroviral drugs and the application of causal inference methodologies to the analysis of longitudinal clinical data. Ms. Petersen is supported by a Pre-Doctoral Fellowship from the Howard Hughes Medical Institute.

M. Sudbrack, Ph.D., studied social psychology in Brazil and France and was until recently a coordinator of HIV/AIDS prevention strategies for the Municipal Health Secretariat of Porto Alegre (state of Rio Grande do Sul). She has recently joined the Brazilian team in charge of fostering South-South Cooperation in the field of HIV/AIDS prevention, management, and care.

M. Colombo, B.Sc., graduated in Psychology. She joined the Municipal Health Secretariat of Porto Alegre as an undergraduate trainee and became involved with different projects in the field of HIV/AIDS prevention. She left her position in early 2005 , after coordinating for 2 years the municipal projects aiming to reduce drug-related harm in deprived communities.

W. T. Caiaffa, M.D., M.P.H., Sc.D., is an Assistant Professor of Epidemiology at the Federal University of Minas Gerais, Belo Horizonte, Brazil. She has been working for more than 20 years in the field of infectious diseases and about 15 years with HIV/AIDS among injection drug users and other related themes such as surveillance, treatment, and care. Dr. Caiaffa has (co-)authored over 40 full papers and/or book chapters on epidemiology, was a NIDA fellow during a post-doctorate at the Johns Hopkins University, and has worked on multiple collaborative projects.

\section{References}

Andrade, T., Lurie, P., Medina, M. G., Anderson, K., Dourado, I. (2001). The opening of South America's first needle exchange program and an epidemic of crack use in Salvador, Bahia-Brazil. AIDS \& Behavior 5:51-64.

Anthony, J. C., Vlahov, D., Nelson, K. E., Cohn, S., Astemborski, J., Solomon, L. (1991). New evidence on intravenous cocaine use and the risk of infection with human immunodeficiency virus type 1. American Journal of Epidemiology 134:1175-1189.

Bastos, F. I. (2000). Drugs and AIDS: a case study from Brazil. Urban Health Development 3:3038 .

Bastos, F. I., Mesquita, F. C., Andrade, T., Telles, P. R., Bueno, R., Dourado, M. I., Hacker, M., Piconez, D., Farias, A. H., the WHO Multicity Study Brazilian Group. (2002a). Declining HIV/AIDS epidemics among IDUs from 3 Brazilian main metropolitan areas. Presented at the 
XIII International Conference on the Reduction of Drug Related Harm, Ljubljana, Slovenia March 3-7.

Bastos, F. I., Pina, M. F., Szwarcwald, C. L. (2002b). The social geography of HIV/AIDS among injection drug users in Brazil. International Journal of Drug Police 13:137-144.

Bastos, F. I., Strathdee, S. A. (2000). Evaluating effectiveness of syringe exchange programmes: current issues and future prospects. Social Science \& Medicine 51:1771-1782.

Bruneau, J., Lamothe, F., Franco, E., Lacanche, N., Desy, M., Soto, J., Vincelette, J. (1997). High rates of HIV infection among injection drug users participating in needle exchange programs in Montreal: results of a cohort study. American Journal of Epidemiology 146:994-1002.

Caiaffa, W. T., Proietti, F. A., Carneiro-Proietti, A. B., Mingoti, S. A., Doneda, D., Gandolfi, D., Reis, A. C. (2003a). The dynamics of the human immunodeficiency virus epidemics in the south of Brazil: increasing role of injection drug users. Clinical Infection Disease 37(Suppl 5):S376-S381.

Caiaffa, W. T., Bastos, F. I., Proietti, F. A., Reis, A. C., Mingoti, S. A., Gandolfi, D., Doneda, D., AjUDE-Brasil II Project. (2003b). Practices surrounding syringe acquisition and disposal: effects of syringe exchange programs from different Brazilian regions. International Journal of Drug Police 14:365-371.

Caiaffa, W. T., Mingoti, S. A., Proietti, F. A., Carneiro-Proietti, A. B., Silva, R. C., Lopes, A. C., Doneda, D. (2003c). Estimation of the number of injecting drug users attending an outreach syringe-exchange program and infection with human immunodeficiency virus (HIV) and hepatitis c virus: the AjUDE-Brasil Project. Journal of Urban Health 80:106-114.

Case, P., Meehan, T., Jones, T. S. (1998). Arrests and incarceration of injection drug users for syringe possession in Massachusetts: implications for HIV prevention. Journal of Acquired Immune Deficiency Syndromes and Human Retrovirology 18(Suppl 1):S71-S75.

Coffin, P. (2000). Syringe availability as HIV prevention: a review of modalities. Journal of Urban Health 77:306-330.

Colombo, M., Sudbrack, M., Gandolfi, D., Malta, M., Bastos, F. I., Caiaffa, W. T. (2003). The role of (ex)drug users as outreach workers in Porto Alegre, Brazil. Presented at the XIV International Conference on the Reduction of Drug Related Harm, Chiang Mai, Thailand April 6-10.

Crofts, N., Costigan, G., Narayanan, P., Gray, J., Dorabjee, J., Langkham, B., Singh, M., Peak, A., Aquino, C., Deany, P. (1998). Harm reduction in Asia: a successful response to hidden epidemics. AIDS 12(Suppl B):S109-S115.

Darke, S. (1998). Self-report among injecting drug users: a review. Drug Alcohol Depend 51:253-263. discussion 267-268

Des Jarlais, D. C., Marmor, M., Paone, D., Titus, S., Shi, Q., Perlis, T., Jose, B., Friedman, S. R. (1996). HIV incidence among injecting drug users in New York City syringe-exchange programmes. Lancet 348:987-991.

Des Jarlais, D. C., Paone, D., Milliken, J., Turner, C. F., Miller, H., Gribble, J., Shi, Q., Hagan, H., Friedman, S. (1999). Audio-computer interviewing to measure risk behaviour for HIV among injecting drug users: a quasi-randomised trial. Lancet 353:1657-1661.

Deslandes, S. F., Mendonca, E. A., Caiaffa, W. T., Doneda, D. (2002). The concepts of risk and prevention from the perspective of injecting drug users [in Portuguese]. Cadernos de Saude Publica 18:141-151.

Dourado, I., Andrade, T., Farias, A., Galvao-Castro, B. (2002). Changing patterns of HIV-1 and HTLV-I/II seroprevalence among IDUs from different districts of Salvador, Brazil: Effectiveness of prevention strategies? Presented at the XIV International AIDS Conference, Barcelona, Spain. July 7-12.

Gibson, D. R., Brand, R., Anderson, K., Kahn, J. G., Perales, D., Guydish, J. (2002). Two-to sixfold decreased odds of HIV risk behavior associated with use of syringe exchange. Journal of Acquired Immune Deficiency Syndromes 31:237-242.

Gostin, L. O. (1998). The legal environment impeding access to sterile syringes and needles: the conflict between law enforcement and public health. Journal of Acquired Immune Deficiency Syndromes and Human Retrovirology 18(Suppl 1):S60-S70. 
Gray, J. (1998). Harm reduction in the hills of northern Thailand. Substance Use \& Misuse 33:10751091.

Hagan, H., Des Jarlais, D. C., Friedman, S. R., Purchase, D., Alter, J. (1995). Reduced risk of hepatitis B and hepatitis C among injection drug users in the Tacoma Syringe Exchange Program. American Journal of Public Health 85:1531-1537.

Hagan, H., McGough, J., Thiede, H., Weiss, N. S., Hopkins, S., Alexander, E. R. (1999). Syringe exchange and risk of infection with hepatitis B and C viruses. American Journal of Epidemiology 149:203-213.

Heimer, R., Clair, S., Teng, W., Grau, L. E., Khoshnood, K., Singer, M. (2002). Effects of increasing syringe availability on syringe-exchange use and HIV risk: Connecticut, 1990-2001. Journal of Urban Health 79:556-570.

Heimer, R., Khoshnood, K., Bigg, D., Guydish, J., Junge, B. (1998). Syringe use and reuse: effects of syringe exchange programs in four cities. Journal of Acquired Immune Deficiency Syndromes and Human Retrovirology 18(Suppl 1):S37-S44.

Kaplan, E. H. (1994). A method for evaluating needle exchange programmes. Statistics in Medicine 13:2179-2187.

Kaplan, E. H., Khoshnood, K., Heimer, R. (1994). A decline in HIV-infected needles returned to New Haven's needle exchange program—client shift or needle exchange. American Journal of Public Health 84:1991-1994.

Lurie, P. (1995). When science and politics collide. Bulletin of the New York Academy of Medicine 72:380-396.

Lurie, P., Reingold, A. L., Bowser, B. (1993). The Public Health Impact of Needle Exchange Programs in the United States and Abroad. Vol. I/II. San Francisco, CA: University of California.

Macalino, G. E., Celentano, D. D., Latkin, C., Strathdee, S. A., Vlahov, D. (2002). Risk behaviors by audio computer-assisted self-interviews among HIV-seropositive and HIV-seronegative injection drug users. AIDS Education and Prevention 14:367-378.

MacDonald, M., Law, M., Kaldor, J., Hales, J., Dore, G. J. (2003). Effectiveness of needle and syringe programmes for preventing HIV transmission. International Journal of Drug Police 14:353-357.

Menoyo, C., Lamikiz, E., Zulaika, D., Urcelaia, A., Zubia, I., Martinez de Pancorbo, M. (1998). The validation of statements by IDUs based on the analysis of blood traces on their used syringes. AIDS Care 10:409-414.

Mesquita, F., Kral, A., Reingold, A., Bueno, R., Trigueiros, D., Araújo, P. J. (2001). Trends of HIV infection among injection drug users in Brazil in the 1990s: the impact of changes in patterns of drug use. Journal of Acquired Immune Deficiency Syndromes and Human Retrovirology 28:298-302.

Metzger, D. S., Koblin, B., Turner, C., Navaline, H., Valenti, F., Holte, S., Gross, M., Sheon, A., Miller, H., Cooley, P., Seage, G. R. 3rd. (2000). Randomized controlled trial of audio computerassisted self-interviewing: utility and acceptability in longitudinal studies. HIVNET Vaccine Preparedness Study Protocol Team. American Journal of Epidemiology 152:99-106.

Porter, J., Metzger, D., Scotti, R. (2002). Bridge to services: drug injectors' awareness and utilization of drug user treatment and social service referrals, medical care, and HIV testing provided by needle exchange programs. Substance Use \& Misuse 37:1305-1330.

Remis, R. S., Bruneau, J., Hankins, C. A. (1998). Enough sterile syringes to prevent HIV transmission among injection drug users in Montreal? Journal of Acquired Immune Deficiency Syndromes and Human Retrovirology 18(Suppl 1):S57-S59.

Rhodes, T., Stimson, G. V., Fitch, C., Ball, A., Renton, A. (1999). Rapid assessment, injecting drug use, and public health. Lancet 354:65-68.

Riley, E. D., Safaeian, M., Strathdee, S. A., Brooner, R. K., Beilenson, P., Vlahov, D. (2002). Drug user treatment referrals and entry among participants of a needle exchange program. Substance Use \& Misuse 37:1869-1886.

Sears, C., Guydish, J. R., Weltzien, E. K., Lum, P. J. (2001). Investigation of a secondary syringe exchange program for homeless young adult injection drug users in San Francisco, California, USA. Journal of Acquired Immune Deficiency Syndromes 27:193-201. 
Sharma, M., Panda, S., Sharma, U., Singh, H. N., Sharma, S., Singh, R. R. (2003). Five years of needle syringe exchange in Manipur, India: Programme and contextual issues. International Journal of Drug Police 14:407-415.

Snead, J., Downing, M., Lorvick, J., Garcia, B., Thawley, R., Kegeles, S., Edlin, B. R. (2003). Secondary syringe exchange among injection drug users. Journal of Urban Health 80(2):330348.

Sorge, R., Harlow, R. E. (1997). Two steps forward, one step back: Anti-user bias in New York State's approach to needle exchange. In: Erickson, P., Riley, D. M., Cheung, Y. W., O’Hare, P. A., eds. Harm Reduction: A New Direction for Drug Policies and Programs. Toronto: The University of Toronto Press.

Stopka, T. J., Singer, M., Santelices, C., Eiserman, J. (2003). Public health interventionists, penny capitalists, or sources of risk? Assessing street syringe sellers in Hartford, Connecticut. Substance Use \& Misuse 38:1345-1377.

Strathdee, S. A., Patrick, D. M., Currie, S., Cornelisse, P. G., Reckart, M. L., Montaner, J., Schechter, M. T., O'Shaugnessy, M. V. (1997). Needle exchange is not enough: lessons from the Vancouver Injection Drug Use Study. AIDS 11:F59-F65.

Strathdee, S. A., van Ameijden, E. J., Mesquita, F., Wodak, A., Rana, S., Vlahov, D. (1998). Can HIV epidemics among injection drug users be prevented?. AIDS 12(Suppl A):S71-S79.

Telles, P. R. (1999). Preventing HIV/AIDS and other sexually transmitted diseases among injecting drug users in Rio de Janeiro. International Journal of Drug Police 10:365-373.

Tyndall, M. W., Bruneau, J., Brogly, S., Spittal, P., O'Shaughnessy, M. V., Schechter, M. T. (2002). Satellite needle distribution among injection drug users: policy and practice in two Canadian cities. Journal of Acquired Immune Deficiency Syndromes 31:98-105.

Valente, T. W., Foreman, R. K., Jungue, B., Vlahov, D. (1998). Satellite exchange in the Baltimore Needle Exchange Program. Public Health Reports 113(Suppl 1):90-96.

van Ameijden, E. J., van den Hoek, A. R., Coutinho, R. A. (1994). Injecting risk behavior among drug users in Amsterdam, 1986 to 1992, and its relationship to AIDS prevention programs. American Journal of Public Health 84:275-281.

van Ameijden, E. J., Coutinho, R. A. (2001). Large decline in injecting drug use in Amsterdam, 1986-1998: explanatory mechanisms and determinants of injecting transitions. Journal of Epidemiology and Community Health 55:356-363.

Vlahov, D., Des Jarlais, D. C., Goosby, E., Hollinger, P. C., Lurie, P. G., Shriver, M. D., Strathdee, S. A. (2001). Needle exchange programs for the prevention of human immunodeficiency virus infection: epidemiology and policy. American Journal of Epidemiology 154(12 Suppl):S70-S77.

\section{Appendix}

Information about NEPs and other projects aiming to reduce harms associated with drug consume can be retrieved as follows:

Initiatives sponsored by the Brazilian Ministry of Health are available at http://www.aids.gov.br

Nongovernmental networks and associations:

Rede Brasileira de Redução de Danos (REDUC)—Brazilian Harm Reduction Network http://www.reduc.org.br/reduc.htm

Associação Brasileira de Redução de Danos (ABORDA)—Brazilian Harm Reduction Association http://www.aborda.org.br/

Rede Latino Americana de Redução de Danos (RELARD)—Latin American Harm Reduction Network http://www.relard.net/ 